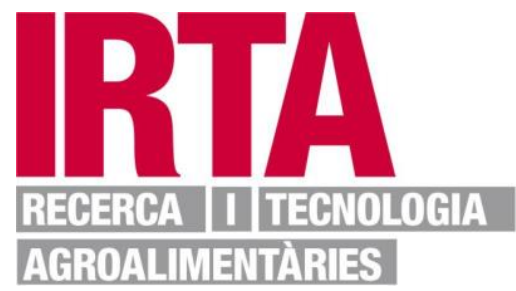

This document is a postprint version of an article published in Diseases Of Aquatic Organisms (c) Inter-Research after peer review. To access the final edited and published work see https://doi.org/10.3354/dao03336

Document downloaded from:

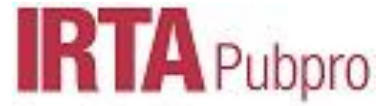

Open dgital archeve 


\title{
Baseline pathological data of the wedge clam Donax trunculus from the Tyrrhenian Sea (Mediterranean Basin)
}

\author{
F. Carella ${ }^{1, *}$, N. Carrasco ${ }^{2}$, G. De Vico ${ }^{1}$
}

${ }^{1}$ Department of Biology, University of Naples Federico II, MSA, 80126 Naples, Italy ${ }^{2}$ IRTA-Sant Carles de la Rapita and Catalonia's Aquaculture R\&D and Innovation Reference Network (XRAq), Ctra. Poblenou Km 5, 43540 Sant Carles de la Rapita, Spain

\begin{abstract}
In recent years, a collapse in Donax trunculus fishing yields has occurred in the Tyrrhenian Sea (Mediterranean Basin). There is little information available on the impact disease may have had on $D$. trunculus populations. For the first time, a pathological survey was performed on the natural beds of the bivalve on the Campania and Lazio coasts, western Italy. Detected pathogens and related diseases were analysed, and their prevalence and mean intensity values were calculated. Viral particles, Chlamydia-like organisms, ciliates, coccidians, microcells and trematodes were observed. An unknown ciliate was linked to severe inflammatory and necrotic lesions in the digestive gland. Metacercariae of the trematode Postmonorchis sp. were also strongly represented in almost all samples, reaching high levels of infection; however, none of the pathogens described required the World Organisation for Animal Health to be notified. I nitial results indicated that further surveys related to environmental data are necessary in order to assess the relevance of these early observations in managing the declining $D$. trunculus population in the Tyrrhenian Sea.
\end{abstract}

KEY WORDS: Wedge clam $\bullet$ Protozoa $\bullet$ Bivalve disease $\bullet$ Trematodes

\section{INTRODUCTION}

Donax trunculus (Bivalvia: Donacidae) is an Atlantic-Mediterranean warm-temperate bivalve species found in the Mediterranean Sea, the Black Sea and in the Atlantic Ocean in coastal regions from Senegal to France. In these environments, D. trunculus populations are distributed in sandy beds between depths of 0-2 $\mathrm{m}$ in the Mediterranean, and from 0-6 $\mathrm{m}$ on the Atlantic coasts, with the highest densities at 0-3 m (Deval 2009). This bivalve represents an important fishery resource due to its high economic value. Landings in Europe over the last $12 \mathrm{yr}$ (since 2006) were 11202 $\mathrm{t}$, with a maximum yield of $1355 \mathrm{t}$ in 2005, followed by a steady decline, with only $516 \mathrm{t}$ in 2011 (FAO 2013). A recent collapse in yields has occurred in the Tyrrhenian Sea of the Mediterranean Basin (de la Huz et al. 2002, Rambaldi et al. 2010, Marie et al. 2016). The causes of this collapse are unclear. Abiotic factors resulting from anthropogenic activity - such as beach nourishment and chemical pollutants - along with extreme meteorological events related to global warming, have been advocated as causing significant persistent changes to the environment of the sandy beds of the Tyrrhenian coast, with serious consequences for the bivalve resources (Rambaldi et al. 2010). However, other environmental stressors associated with climate change may also have facilitated the spread of diseases into previously unaffected shellfish populations, exacerbated disease where it already exists or facilitated the emergence of novel pathogens, which also may have caused severe losses. There is very little information available on the prevalence and distribution of disease in D. trunculus populations in the Mediterranean Sea. Although pathogens such as Rickettsia/ Chlamydia-like organisms (RLOs/CLOs), nematodes and trematodes have been described as parasites of Donax spp. (Sindermann \& Rosenfield 1967, Comps \& Raimbault 1978, Ansell 1983, de Montaudouin et al. 2014), few studies have reported specifically on $D$. trunculus, and little is known of the pathogens that may adversely affect the health of these populations. In general, trematodes are the most often described parasites of the family Donacidae, including Fellosto- midae and Monorchidae (Palombi 1933a,b, Carella et al. 2013, de Montaudouin et al. 2014). 
In the present study, we sampled D. trunculus from the Tyrrhenian Sea over several years and describe the pathogens and diseases found using histopathol- ogy and molecular techniques to provide baseline data on the health status of this species.

\section{MATERIALS AND METHODS}

\subsection{Sampling}

From 2008 to 2015,330 wedge clams $D$. trunculus were collected during the summer or autumn from different geographical areas. The sampling sites in the Campania region were the Volturno River mouth ( $41^{\circ} 0^{\prime} 57^{\prime \prime} \mathrm{N}, 13^{\circ} 56^{\prime} 50^{\prime \prime}$ E) from July 2008 to 2010 (90 clams) and Litorale Domitio $\left(41^{\circ} 4^{\prime} 8\right.$ "N, 13 $3^{\circ} 51^{\prime} 4 " \mathrm{E}$ ) from June and July 2012 (60 clams) and June 2014 and 2015 (60 clams). In September 2012, samples were also collected at Formia ( $\left.41^{\circ} 14^{\prime} 21^{\prime \prime} \mathrm{N}, 13^{\circ} 36^{\prime} 43^{\prime \prime} \mathrm{E}\right)$ (30 clams) in the Lazio region. In October 2013, clams were collected in 3 areas of Salerno Province including Foce Sele (30 clams) $\left(40^{\circ} 29^{\prime} 02^{\prime \prime} \mathrm{N}, 14^{\circ} 56^{\prime} 29^{\prime \prime} \mathrm{E}\right)$, Foce Tusciano (30 clams) $\left(40^{\circ} 34^{\prime}\right.$

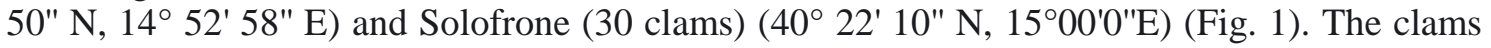
were sampled from the shore using a hand-held semi-circular dredge as used by the local fishermen.

\subsection{Animal tissue processing}

The animals were opened in the laboratory and examined for external signs of pathology under a dissecting microscope (Nikon SMZ-10). The bivalves were then fixed in Davidson's fixative for 24 to $48 \mathrm{~h}$ and processed for routine histopathology. Additionally, pieces of digestive gland, gills and gonads were also preserved from each animal for further molecular and transmission electron microscopy (TEM) analysis. For histopathology, 2 transverse sections, approx. $5 \mathrm{~mm}$ thick, including the mantle, gonad, digestive gland, gills, kidney and foot, were excised from each clam and placed into histological cassettes. The tissue samples were embedded in paraffin wax, sliced in $5 \mathrm{pm}$ sections and subsequently stained with haematoxylin and eosin (H\&E). For better characterization of the tissue, additional stains, such as PAS-BA and Masson's Trichrome (Mazzi 1977), were also used on selected slides from every sampled area. Furthermore, to improve the characterization of the prokaryote-like inclusions, additional staining techniques were used: Gram's method for Gram-positive and Gram-negative bacteria, Macchiavello stain (Mazzi 1977) and Giemsa (Howard \& Smith 1983). All micrographs were captured using a Nikon DS-Fi1 video camera mounted on a Nikon 50i microscope connected to a computer. Histological sections were examined for the presence of parasites and pathological alterations. Pathogen prevalence $(P)$ and mean intensity $(I)$ of the different parasites were calculated. For evaluation of the infection intensity of trematodes such as Postmonorchis sp. present in gill tissue, data were obtained by histological examination (histological infection density, HID) as described by Carella et al. (2013).

The percentage of clams affected by each parasite and their pathological condition were determined for each sampled bed included in the survey. The overall prevalence (and 95\% CI) of each parasite and pathological condition were calculated for the whole study.

\subsection{TEM}

After histological examination, small pieces of digestive gland parasitized by protozoa and individuals with digestive glands that had a foamy aspect at the level of A cells under light microscopy were selected from the stored tissues for ultrastructural analysis by TEM.

Tissues were fixed in $2 \%$ glutaraldehyde in filtered seawater for $24 \mathrm{~h}$ at $4{ }^{\circ} \mathrm{C}$, post-fixed in $2 \%$ tetroxide osmium $\left(2 \mathrm{~h}\right.$ at $\left.4^{\circ} \mathrm{C}\right)$ and embedded in EPON. Ultrathin sections $(70-90 \mathrm{~nm})$ were cut, the tissues were stained with uranyl acetate and lead citrate and were observed using a JEOL 100 CX2 transmission electron microscope at the Centro Interdipartimentale di Servizio per la Microscopia Elettronica (CISME), University of Naples. 


\subsection{Molecular identification of RLOs/CLOs}

For RLO/CLO identification, DNA isolation was performed from pieces of digestive gland previously preserved in $96 \%$ EtOH. DNA extractions were performed employing the DNeasy Blood and Tissue Kit (Qiagen) following the manufacturer's instructions. The DNA concentration was measured using a Nanodrop 2000c spectrophotometer (ThermoScientific), and DNA quality was verified by electrophoresis on a $1 \%$ agarose gel stained with ethidium bromide.

The 16S primers RCF/RCR described by Costa et al. (2012) for Rickettsia/Chlamydia-like bacteria were used. The PCR mixture consisted of $0.4 \mathrm{pM}$ of each primer RCF/RCR (Sigma), PCR reactions were carried out using PCR buffer at $1 \mathrm{x}$ concentration, $1.5 \mathrm{mM} \mathrm{MgCl}_{2}, 200 \mathrm{pM}$ of each deoxynucleotide (dNTP mixture; Takara Bio) and 1 unit of Taq DNA Polymerase (Invitrogen), $2 \mathrm{pl}$ of template DNA was added to the mixture to make a final volume of $25 \mathrm{pl}$. After a denaturation step at $94^{\circ} \mathrm{C}$ for $5 \mathrm{~min}, 30$ cycles were run with an Eppendorf thermal cycle as follows: denaturation at $94^{\circ} \mathrm{C}$ for $1 \mathrm{~min}$, annealing at $51^{\circ} \mathrm{C}$ for $1 \mathrm{~min}$ and elongation at $72^{\circ} \mathrm{C}$ for $1 \mathrm{~min}$. A final elongation step at $72^{\circ} \mathrm{C}$ for $10 \mathrm{~min}$ was performed.

The PCR products were run on $1.2 \%$ agarose gel. The amplified fragments were gel-eluted and directly sequenced. The sequencing reactions were run on a 310 Automated Sequencer (Applied Biosystems). The best BLAST hits for the obtained nucleotide sequences were downloaded and aligned with their corresponding sequences using ClustalW. The alignment files were employed to construct neighbour-joining trees using the software MEGA v.7 (Kumar et al. 2016).

\section{RESULTS}

A total of 330 wedge clams from the Lazio and Campania regions were examined. Histopathological analysis revealed different symbionts and pathological conditions affecting Donax trunculus. Observed pathogens and their tropism are shown in Fig. 2; see also Table 1 \& Figs. 3-9.

\subsection{Viral infection}

Under light microscopy, in specimens from Litorale Domitio from 2014 and 2015, some A cells of the digestive epithelium were vacuolated and foamy. TEM examination of the digestive tubules from 3 cases from 2014 and 2 from 2015 showed the presence of viral particles $60 \mathrm{~nm}$ in dimension in A cells. The virions exhibited an icosahedral symmetry (Fig. 3). Moreover, cytoplasmic viral factories (where viral replication and assembly likely take place) constituted by both electron-dense cytoplasmic inclusions and membrane vesicles were visible (Fig. 3 insert).

\subsection{Prokaryote infection by CLOs}

During histology, light microscopy observations of H\&E-stained tissues revealed rounded intracellular inclusions of prokaryote-like colonies. The inclusions were (mean \pm SD) $7.65 \pm 1.79$ $\mathrm{pm}$ in length and were found in the epithelium of the digestive gland in clams from all localities. These colonies occupied the cytoplasm of the A cells of the digestive tubules, in some cases causing hypertrophy or destruction (Fig. 4A,B). In some cases, an infiltrative mild/strong haemocytic reaction was detected. The colonies were positive for Rickettsia/Chlamydia by Macchiavello and Giemsa staining (Fig. 4C,D). Most infected clams had 8 to 20 inclusions section $^{-1}$, but a few clams had 20 to 30 inclusions section ${ }^{-1}$. The maximum $P$ and mean $I$ were recorded in Litorale Domitio in 2015 (83\%), with 30 colonies per histological section. No prokaryote-like colonies were observed at Foce Sele and Solofrone in October 2013 (Table 1). PCR amplification was run on 3 samples from Volturno (2008 and 2009), 3 samples from Litorale Domitio (2012) and 2 samples from Formia (2012) on a 350 bp region produced by the partial 16SrRNA. BLAST analysis revealed $100 \%$ identity among all the sequences, and the best nucleotide identity score (92\%) was obtained for various strains of Clamydia- like bacteria, such as Chlamdya pecorum, C. ibidis and Estrella lausannensis (Fig. 5). The sequences were deposited in Genebank (accession no. MH492627). 
Two different types of ciliates were observed: one located in the gills and another in the digestive gland. Moreover, oocytes of the gregarine Nematop- sis sp. were also detected in the connective tissue of the digestive gland and gills (Fig. 6). These oocysts were oval in shape, had a maximum dimension of $($ mean $\pm \mathrm{D}) 9.49 \pm 1.24 \mathrm{pm}(\mathrm{n}=20)$ and usually contained 1 sporozoite oocyst ${ }^{-1}$. Ciliated protozoa wereobserved adjacent to the gills (Fig. 6A). They were oval-shaped, had dense ciliature and measured 10 to $12 \mathrm{pm}$ in length. They may have been Hypocomella sp., which have been described in other bivalve species, but no reports have occurred in the wedge clam. The ciliates had 2 nuclei (macro- and micronucleus). They did not appear to cause any specific host response. The maximum $P$ were 36\% in Foce Sele and 40\% in Tusciano in 2013.

In 2 samples from 2014 and 1 sample from 2015, the presence of small protozoans similar to haplosporidian microcell parasites were detected in different tissues of $D$. trunculus from Litorale Domitio (June 2015), particularly in muscular and connective tissues and the intracellular space within haemocytes (Fig. 6C,D). The infection was focal and low for any given organ. They mostly resembled the Mikrocytos-like parasite previously described by Garcia et al. (2018), while for the immune cell tropism they were similar to other microcells belonging to Bonamia species.

An unidentified ciliate endoparasite was detected in the interstitial spaces of digestive tubules in the digestive gland (Fig. 7). The parasite was present in every sampled area, showing a high prevalence and infection intensity, with an overall $P$ of 219 (Fig. 7A). The parasite was always accompanied by an intense inflammatory reaction, and in some cases it was asso ciated with focal necrosis of the digestive tubules and intestinal epithelia (Fig. 7B). Generally, the parasites were grouped with others and were often present at the haemo-lymphatic sinus level, eating host haemo- cytes (Fig. 7C,D). Morphologically, the ciliates were ovoid with a tapered anterior end and round in crosssection. They had an estimated maximum body width

\subsection{Metazoa}

Metacercarie of the trematode Postmonorchis sp., as previously described by Carella et al. (2013), were also detected (Fig. 8A-C). They were located at the gill level and were distributed across the upper, middle and lower part of filaments, in many cases reaching high infection intensity and macroscopic visibility (Fig. 8A). The mean diameter of the cysts was (mean \pm SD) 180-220 \pm $23.82 \mathrm{pm}(\mathrm{n}=50)$. In a few cases, the parasite was detected in the foot, the stomach and the kidney-pericardium system. The inflammatory response included encapsulation and ranged from mild to intense in gill tissues, eliciting hypertrophy and hyperplasia of the gill epithelia.

Different phases of development of the metacer- caria were observed. In fact, some of them had a smaller dimension ( 160 pm) and a thinner cyst wall compared to other metacercariae (Fig. 8B). In these cases, the pathogen appeared to be more susceptible to the host inflammatory response. Other histopatho- logical findings included mild hypertrophy or hyperplasia of mucus cells and the connective tissue of the gills, as demonstrated by PAS-BA and Trichrome staining. A higher prevalence was detected in the northern part of the Campania region, at the Volturno River mouth in 2008 and 2009.

Sporocysts of the Fellodistomidae trematode Bac-ciger bacciger (Rudolphi 1819) were observed in D. trunculus in all localities except for the areas of Salerno Province. Sporocysts containing developing cercariae were found mostly in the gonad, but also in the foot, mantle and/or the whole visceral mass (Fig. 8D). The fully developed cercaria showed a seti- ferous tail, eosinophilic staining and an ovoid body of $310 \pm 52 \mathrm{pm}(\mathrm{n}=10)$ (Fig. $8 \mathrm{E})$. When present, the parasite generally showed heavy infection intensity. The tissues of the gonad and digestive gland of these clams were replaced bya sporocysts and cercariae that caused intense damage and host castration. Animals did not show a haemocyte reaction to the pathogen. Within the sporocyst, the cercariae were typically in the same range of deveolopmental stages. 
This study revealed, for the first time, the occurrence of different pathogens and related pathological conditions affecting the wedge clam Donax trunculus along the Campania and Lazio coasts.

The presence of viral particles in A cells of the digestive gland were observed in our study. Previous reports described 2 types of birnavirus in the bivalve Tellina tenuis, tellina virusl (TV1) and tellina virus2 (TV-2) (Chung \& Paetzel 2013, Nobiron et al. 2008), in digestive tubule cells. TV-1 was described in connection with a population of diseased T. tenuis with watery flesh. Infected animals had atrophic digestive tissues and were markedly thinner than healthier specimens (Renault \& Novoa 2004, Nobiron et al. 2008). The virus showed morphological and physio- chemical characteristics similar to infectious pancre atic necrosis virus (IPNV), an aquabirnavirus that infects salmonid fishes (Hill 1976, Underwood et al. 1977). On the basis of their location and dimension, the virions observed in our case were in concordance with the above-mentioned reports; however, further studies are needed to definitely assign them to this group.

RLOs and CLOs are obligate, intracellular bacterial parasites associated with a variety of vertebrate and invertebrate hosts (Gollas-Galvan et al. 2014). Several authors have documented the presence of RLOs/CLOs in many aquatic animals, including fish, molluscs and crustaceans (Gulka \& Chang 1984, Wang \& Gu 2002, Sun \& Wu 2004), with most of the literature focused on teleost fishes and bivalve molluscs. In some cases, these pathogens are causative agents of severe mortality outbreaks in farmed aquatic species such as the Rickettsia Candidatus Xenohaliotis californiensis that causes mass mortalities of Haliotis spp. in many countries (Crosson et al. 2014). However, little is known about the pathogen's life cycle or host range (Ferrantini et al. 2009). In this study, the observed intracellular bacteria were recorded within the cytoplasmic vacuoles of the digestive gland epithelium of $D$. trunculus. In many cases, the immune response of the host was mild. Only some specimens had digestive epithelia destruction as reported by Comps \& Raimbault (1978). Our molecular study revealed that the prokaryotic inclusion in the digestive gland belonged to Chlamydi-ales, as also reported by Costa et al. (2012) in Rudi-tapes decussatus. Interestingly, in contrast to RLOs, which have been described in different tissues in bivalves, CLOs have been reported only in digestive tubules. In particular, a study by Renault \& Cochen- nec (1995) reported the presence of Chlamydia sp. in the Japanese oyster Crassostrea gigas, where indirect fluorescent and peroxidase conjugated antibody tests suggested that this agent might share common antigens with the prokaryotic agent Chlamydia psittaci, strain ovis. Infections by members of the genera Chlamydia have been described in a variety of adult bivalve molluscs, with reports in bivalves in Chesapeake Bay by Harshbarger et al. (1977), in Mercenaria mercenaria from the Great South Bay (Meyers 1979) in Argopecten irradians in Canada (Morrison \& Shum 1982) and in mussels from Basque Country (Cajaraville \& Angulo 1991).

Regarding protists, the gregarine Nematopsis sp. was not highly represented, with no possible species identification. This parasite has not been previously reported in $D$. trunculus, but Nematopsis sp. has been reported in different bivalve species such as Mytilus galloprovincialis (Carella 2010), R. decussa- tus and Cerastoderma glaucum (Longshaw \& Mal-ham 2013).

Ciliate parasites are very common organisms in bivalves (Bower et al. 1994). In this study, 2 types of ciliates were observed. One was present adjacent to the gills and caused evident damage. An unidentified ciliate was observed in the digestive tissues of specimens in all the sampled areas and had high prevalence and infection intensity. The protozoa were characterized by the presence of cilia, a rounded nucleus and an elongated, tube-shaped body structure. The cytoplasm of the ciliates was typically full of food vacuoles, which appeared to contain debris. Our study showed that ciliate infections can cause significant morbidity related to intense tissue damage. Other studies reported the detrimental effects of ciliated protozoa on the digestive tissue of bivalves. Elston et al. (1999) described mortality episodes linked to an invasive opportunistic ciliate belonging to Scuticociliatida. The same group of protozoa has been described in other bivalve species and in crustaceans where infection is fatal (Morado \& Small 1994, 1995, Cawthorn et al. 1996). We still do not have a specific taxonomic affiliation for the observed protozoa in $D$. trunculus from the Tyrrhenian area. Further molecular analyses are needed to identify the observed pathogen. 
Microcell parasites are small intracellular protozoans mostly detected in molluscs, and they can

be associated with high mortality rates. They are essentially mollusc parasites represented by 2 genera: Bonamia and Mikrocytos (Carnegie \& Cochennec- Laureau 2004). Microcell-like parasites were detected at low prevalence in our samples in the muscles and connective tissues, and the infection was focal and low for any given organ. This was the first time that a microcell parasite has been detected in Italy. Further molecular analyses are required in order to classify the organism.

Metazoan parasites detected in this survey included different phases of development of digenean trematodes. B. baccigerwas reported by Ramon et al. (1999), with adult phases originally discovered by Rudolphi (1819) in marine fishes. In bivalves, the literature reports that heavy sporocyst infiltration of $B$. bacciger can cause complete castration and depletion of body energy, with host soft tissues becoming empty and watery (Lauckner 1983). On the French Atlantic and Italian Mediterranean coasts, the parasite caused large-scale fluctuations in the abundance of Ruditapes spp. and D. vittatus populations. It was also previously reported in the Campania region by Palombi (1933a,b) at Fusaro Lagoon, with higher prevalence during the spring from March to May. In our study, the samples were all collected during the summer season, with a higher infection prevalence in Litorale Domitio in 2014 and 2015.

Metacercariae of Postmonorchis sp. have already been described by Carella et al. (2013). The prevalence of the pathogen ranged from 76 to $100 \%$, while the infection intensity fluctuated in the study areas. An inflammatory response was always recorded in parasitized animals and was characterized by inflammatory capsules that adhered to and enclosed the foreign body; such responses were, in some cases, ineffective against completely formed metacercariae with a thicker covering, as already reported (Carella et al. 2013).

Young (1953) described Postmonorchis donacis from the Pacific coast of the United States. The adult phases were found in teleosts belonging to the families Sciaenidae and Embiotocidae, and cercariae and metacercariae were detected in the bean clam D. gouldii. The reported metacercariae of Postmonorchis sp. in D. trunculus showed a combination of features of the 3 described species of Postmonorchis present in the literature: P. variabilis, P. orthopristis and $P$. donacis.

In conclusion, the present study was the first attempt to identify pathogens of D. trunculus collected from a natural shellfish bed on the Tyrrhenian coast, combining histological and molecular analyses that should be useful as a reference in future health surveys. Gill ciliates, Nematopsis sp., and Chlamydialike colonies seemed to have limited pathogenicity and light infection intensity. On the other hand, based on their pathogenic potential, the observed viral particles, ciliated protozoa, bucephalid sporo- cysts and monorchidae metacercariae caused heavy infections.

Among the protozoa, the unidentified ciliate protozoan in the digestive gland was significant for its high prevalence and was possibly detrimental to the wedge clam populations. None of the observed parasites are on the list of obligatory notification of the World Organization for Animal Health (OIE).

In this study, infections with microcell parasites were observed in a few specimens of $D$. trunculus. In France, these parasites caused animal mortality (Garcia et al. 2018). Based on morphological characteristics and its detection in the wedge clam, we consider that the pathogen probably belongs to the novel Mikrocytos species detected in France. This underlines the possible importance of including microcells on the list of potential disease agents.

Our data is limited to one season with corresponding environmental parameters. However, these initial results show that further surveys related to environmental data and seasons are necessary in order to assess the relevance of the pathogens and diseases observed in this declining $D$. trunculus population in the Tyrrhenian Sea.

Acknowledgements. The authors acknowledge Dr. Grazia Villari for technical assistance with histology. The authors also thank Dr. Francesco Bolinesi who provided technical assistance in sampling in Salerno Province. The authors acknowledge the Nucleo Carabinieri Subacquei of Napoli for field and diving support in the area of Volturno and Litorale Domitio. Sample processing and examination with TEM were performed by the CISME (University of NaplesDepartment of Biology) with technical assistance from Dr. Sergio Sorbo. 
Bower SM, McGladdery SE, Price IM (1994) Synopsis of infectious diseases and parasites of commercially exploited shellfish. Annu Rev Fish Dis 4:1-199

Cajaraville MP, Angulo E (1991) Chlamydia-like organisms in digestive and duct cells of mussels from the Basque coast. J Invertebr Pathol 58:381-386

Carella F (2010) Biotechnologies to evaluate the environmental status: new test organisms in ecotoxicology and histopathological and molecular biomarkers in natural population. PhD thesis, University of Naples Federico II

Carella F, Culurgioni J, Aceto S, Fichi G, Pretto T, Luise D, Gustinelli A (2013) Postmonorchis sp. inq. (Digenea: Monorchiidae) metacercariae infecting natural beds of wedge clam Donax trunculus in Italy. Dis Aquat Org 106: 163-172

Carnegie RB, Cochennec-Laureau N (2004) Microcell parasites of oysters: recent insights and future trends. Aquat Living Resour 17:519-528

Cawthorn RJ, Lynn DH, Despres B, MacMillan R, Maloney R, Loughlin M, Bayer R (1996) Description of Anophryoides haemophila n. sp. (Scuticociliatida: Orchitophryidae), a pathogen of American lobsters Homarus americanus. Dis Aquat Org 24:143-148

Chung IY, Paetzel M (2013) Tellina virus 1 VP4 peptidase. In: Rawlings ND, Galvesen G (eds) Handbook of proteolytic enzymes, Vol 3. Academic Press, Amsterdam, p 3523-3527

Comps M, Raimbault R (1978) Infection rickettsienne de la glande digestive de Donax trunculus Linné. Sci Pêche 281:11-12

Costa PM, Carreira S, Lobo J, Costa MH (2012) Molecular detection of prokaryote and protozoan parasites in the commercial bivalve Ruditapes decussatus from southern Portugal. Aquaculture 370-371:61-67

Crosson LM, Wight N, Van Blaricom GR, Kiryu I, Moore JD, Friedman CS (2014) Abalone withering syndrome: distribution, impacts, current diagnostic methods and new findings. Dis Aquat Org 108:261-270

de la Huz R, Lastra M, López J (2002 ( The influence of grain size on burrowing, growth and metabolism of Donax trunculus L. (Bivalvia: Donacidae). J Sea Res 47: 85-95

de Montaudouin X, Bazairi H, Ait Mlik K, Gonzalez P (2014) Bacciger bacciger (Trematoda: Fellodistomidae) infection effects on wedge clam Donax trunculus condition. Dis Aquat Org 111:259-267

Deval MC (2009) Growth and reproduction of the wedge clam (Donax trunculus) in the Sea of Marmara, Turkey. J Appl Ichthyol 25:551-558

Elston RA, Cheney D, Frelier P, Lynn D (1999) Invasive orchitophryid ciliate infections in juvenile Pacific and Kumomoto oysters, Crassostrea gigas and Crassostrea sikamea. Aquaculture 174:1-14

FAO (2013) Fisheries Global Information System (FIGIS). www.fao.org/fishery/statistics/global-capture-production/query/en, 2013

Ferrantini F, Fokin SI, Modeo L, Andreoli I, Dini F, Gortz HD, Petroni G (2009) 'Candidatus Cryptoprodotis polytropus', a novel Rickettsia-like organism in the ciliated protist Pseudomicrothorax dubius (Ciliophora, Nassophorea). J Eukaryot Microbiol $56: 119-129$

Garcia C, Haond C, Chollet B, Nerac M and others (2018) Descriptions of Mikrocytos veneroïdes n. sp. and Mikrocytos donaxi n. sp. (Ascetosporea: Mikrocytida: Mikrocytiidae), detected during important mortality events of the wedge clam Donax trunculus Linnaeus (Veneroida: Donacidae), in France between 2008 and 2011. Parasit Vectors 11:119

Gollas-Galvan T, Avila-Villa LA, Martınez-Porchas M, Hernandez-Lopez J (2014) Rickettsia-like organisms from cultured aquatic organisms, with emphasis on necrotizing hepatopancreatitis bacterium affecting penaeid shrimp: an overview on an emergent concern. Rev Aquacult 6:256-269

Gulka G, Chang PW (1985) Pathogenicity and infectivity of a rickettsia-like organism in the sea scallop, Placopecten magellanicus. J Fish Dis 8:309-318

Harshbarger JC, Chang SC, Otto SV (1977) Chlamydiae (with phages), mycoplasmas, and rickettsia in Chesapeake Bay bivalves. Science 196:666-668

Hill BJ (1976) Properties of a virus isolated from the bivalve mollusc Tellina tenuis (Da Costa). In: Page LA (ed) Wildlife diseases. Plenum Press, New York, NY, p 445-452

Howard DW, Smith CS (1983) Histological techniques for marine bivalve mollusks. NOAA Tech Memo NMFSF/NEC-25. National Oceanic and Atmospheric Administration, Woods Hole, MA

Kumar S, Stecher G, Tamura K (2016) MEGA7: molecular evolutionary genetics analysis version 7.0 for bigger datasets. Mol Biol Evol 33:1870-1874

Lauckner G (1983) Diseases of Mollusca. Bivalvia. In: Kinne O (ed) Diseases of marine animals, Vol 11. Biologische Anstalt Helgoland, Hamburg, p 477-961

Longshaw M, Malham SK (2013) A review of the infectious agents, parasites, pathogens and commensals of European cockles 
Marie AD, Lejeusne C, Karapatsiou E, Cuesta JA and others (2016) Implications for management and conservation of the population genetic structure of the wedge clam Donax trunculus across two biogeographic boundaries. Sci Rep 6:39152

Mazzi V (1977) Manuale di tecniche istologiche e istochimiche. Piccin, Rome Meyers TR (1979) Preliminary studies on a chlamydial agent in the digestive diverticular epithelium of hard clams Mercenaria mercenaria (L.) from Great South Bay, New York. J Fish Dis 2:179-189

Morado JF, Small EB (1994) Morphology and stomatogenesis of Mesanophrys pugettensis n. sp. (Scuticociliatida: rchitophryidae), a facultative parasitic ciliate of the Dungeness crab, Cancer magister (Crustacea: Decapoda). Trans Am Microsc Soc 113:343-364

Morado JF, Small E (1995) Ciliate parasites and related diseases of Crustacea: a review. Rev Fish Sci 3:275-354 Morrison C, Shum C (1982) Chlamydia like organisms in the digestive diverticula of the bay scallop, Argopecten irradians (Lmk). J Fish Dis 5:173-184

Nobiron I, Galloux M, Henry C, Torhy C and others (2008) Genome and polypeptides characterization of Tellina virus 1 reveals a fifth genetic cluster in the Birnaviridae family. Virology 371:350-361

Palombi A (1933a) Bacciger bacciger (Rud.) Nicoll, 1914, forma adulta di Cercana pectinata Huet, 1891. Boll Soc Nat Napoli 44:217-219

Palombi A (1933b) Cercaria pectinata Huet et Bacciger bacciger (Rud.) Rapporti genetici e biologia. Boll Zool 4:1-11

Rambaldi E, Lanni L, Pelusi P, Binda F and others (2010) Valutazione dei banchi naturali di molluschi bivalvi eduli (telline, Donax trunculus e cannolicchi, Ensis siliqua) lungo la fascia costiera della provincia di latina e indicazioni gestionali per una pesca sostenibile. Biol Mar Mediterr 17:328-329

Ramòn M, Gracenea M, Gonzales-Moreno O (1999) Bacciger bacciger (Trematoda, Fellodistomidae) infection in commercial clams Donax trunculus (Bivalvia, Donacidae) from the sandy beaches of the Western Mediterranean. Dis Aquat Org 35:37-46

Renault T, Cochennec N (1995) Chlamydia-like organisms in ctenidia and mantle cells of the Japanese oyster Crassostrea gigas from the French Atlantic coast. Dis Aquat Org 23:153-159

Renault T, Novoa B (2004) Viruses infecting bivalve molluscs. Aquat Living Resour 17:397-409

Rudolphi CA (1819) Entozoorum synopsis cui accedunt mantissa duplex er indices locupletissimi. Riicker, Berlin

Sindermann CJ, Rosenfield A (1967) Principal diseases of commercially important marine bivalve Mollusca and Crustacea. Fish Bull 66:335-385

Sun J, Wu X (2004) Histology, ultrastructure, and morphogenesis of a rickettsia-like organism causing disease in the oyster, Crassostrea ariakensis Gould. J Invertebr Pathol 86:77-86

Underwood BO, Smale CJ, Brown F, Hill BJ (1977) Relationship of a virus from Tellina tenuis to infectious pancreatic necrosis virus. J Gen Virol 36:93-109

Wang W, Gu Z (2002) Rickettsia-like organism associated with tremor disease and mortality of the Chinese mitten crab Eriocheir sinensis. Dis Aquat Org 48:149-153

Young RT (1953) Postmonorchis donacis, a new species of monorchid trematode from the Pacific coast, and its life history. J Wash Acad Sci 43:88-93 